\title{
Assessment of Paddy Drum Seeder (8 Row) for Line Sowing of Sprouted Paddy Seed
}

\author{
Anita Lakra ${ }^{1 *}$, Narayan Sahu ${ }^{2}$ and Diproshan Banjara ${ }^{3}$ \\ ${ }^{1}$ Agricultural processing \& Food Engineering, Krishi Vigyan Kendra, Dantewada, India \\ ${ }^{2}$ Krishi Vigyan Kendra, Dantewada, India \\ ${ }^{3}$ Agronomy, Krishi Vigyan Kendra, Dantewada, India \\ *Corresponding author
}

\begin{tabular}{|l|}
\hline Ke y w o r d s \\
Paddy drum seeder, \\
Line sowing, \\
$\begin{array}{l}\text { Sprouted paddy } \\
\text { seed }\end{array}$ \\
\hline Article Info \\
\hline $\begin{array}{l}\text { Accepted: } \\
\text { 17 June } 2020 \\
\text { Available Online: } \\
\text { 10 July } 2020\end{array}$ \\
\hline
\end{tabular}

\section{A B S T R A C T}

Rice is major crop in the Dantewada district of Chhattisgarh and about 80 to $90 \%$ of rice cultivation area the farmers doing traditional methods for sowing of paddy i.e. broadcasting of seed. These methods have some problem i.e. poor yield, improper plant population etc. To overcome these types of problems and to make awareness of agricultural machineries the present investigation "Assessment of paddy drum seeder for line sowing of sprouted paddy seed" was conducted in order to reduce labour as well as input cost. In the investigation, we used two different methods of paddy sowing i.e. T1 - traditional method - (broadcasting) and T2 - Sowing of pre-germinated seed by eight row paddy drum seeder. Two different villages of District Dantewada of Chhattisgarh during year Kharif 201920 was selected. The results shown that the treatment T1 and T2 gave the average net income $38587 \mathrm{Rs} / \mathrm{ha}$ and $48237 \mathrm{Rs} / \mathrm{ha}$ respectively. Traditional method gave yield (q/ha.) and B:C ratio were recorded $21 \mathrm{q} / \mathrm{ha}$ and 1.66 respectively. Sowing of paddy by paddy drum seeder gave yield q/ha and B:C ratio were recorded 26.28 $\mathrm{q} / \mathrm{ha}$ and 2.42 respectively. In spite of increased in yield, the improved technology gave higher net return, benefit/cost ratio and reduction in cultivation costs than farmers practices.

\section{Introduction}

Rice (Oryza sativa L.) is the most consumed cereal grain in the world, constituting the dietary staple food for more than half of its human population. India, the second largest producer after China, has an area of over 43.95 million hectares under rice with production and yield of 106.29 million tones and $2424 \mathrm{~kg}$ per hectare of rice respectively in 2013-14.

The labour requirement is very Intense at the time of transplanting season. Wet paddy seeding can reduce the labour requirement during transplanting season. The direct wet 
rice seeding also reduces the water requirements of crop and it saves at least 1015 days in the crop growth period. Therefore, direct wet seeding of pre-germinated seed would be very useful for the small rice farmers. The wet seeding technology is very simple and can be adopted by the farmers easily. The pre- germinated seeds are prepared by soaking the paddy seeds for 24 hours in water and after soaking they are incubated for 12 hours till 1 to $2 \mathrm{~mm}$ size sprouts are visible. The wet seedbed is prepared by shallow pudding with tractor cage wheel in fully saturated soil and allowed 12 hours with a thin layer of water is good for sowing the pre-germinated rice seed preferably under anaerobic conditions.

Eight row paddy drum is manually operated low cost equipment and it is simple in construction. The advantage of drum seeder is that row to row spacing can be easily maintained and dropping of seeds in hills is possible. Drum seeder is an effective mean for timely sowing of rice (Subbaiah et al., 2002). Therefore the study was undertaken to evaluate the performance of paddy drum seeder in puddle rice fields.

\section{Materials and Methods}

The present study was carried out at two different villages of district Dantewada of Chhattisgarh A low cost and manually operated KSNM Direct Paddy Seeder was developed and certified by Tamil Nadu Agriculture University, Coimbatore, India. Drum seeder consists of four cylindrical seed drums made of plastic, ground wheels, floats and handle. The seed drum having volume $250 \mathrm{~mm}$ x $180 \mathrm{~mm}$ with $40 \mathrm{~cm}$ length. Nine numbers of seed metering hole (funnel shaped) of $8 \mathrm{~mm}$ diameter were provided along the circumference of the drum at both the ends with row to row spacing of $20 \mathrm{~cm}$. using a drum seeder in a well puddle and level wet field. The seeds are dropped in rows @ $20 \mathrm{~cm}$ row to row spacing and the seed rate is about $63 \mathrm{~kg}$ per hectare of MTU1010 variety of rice was taken in the experimentation. Drum seeder is light in weight, easy to operate and more area can be covered by a single man.

T1, Traditional method: broadcasting of germinated seeds after the field preparations, these methods have some problem i.e. poor yield, improper plant population etc.

T2, Direct sowing with drum seeder, the paddy seeds were soaked in water for 24 hours followed by incubation in gunny bags for 24-48 hours.

The field was well puddle and leveled after draining the standing water before sowing to avoid damage of sprouted seed and to enable water to spread uniformly over the field. After puddling, the field was left for 1-2 days for settling of the puddle soil. Care was taken to maintain thin film of water in the field at the time of sowing. Seed rate required for direct sowing of sprouted seed in puddle fields was quantified and pre germinated seeds were filled in all drums upto $2 / 3$ rd of its capacity at a time. After turning the drum seeder for second row, care should taken that the first wheel should go through the same line of previous row in order to maintain the inter row distance of $20 \mathrm{~cm}$, care should be taken to watch for any blocks of the drum. Refill the drums with seed when it reaches to the 1/4 th of its capacity and continue the operation. Minimum two labour were required for completing the sowing operation i.e. one labour is for pulling the seeder and the other is for checking the drop of seeds from holes and filling the pre-germinated seeds in the drum. The field was kept moist without standing water in the field upto 20 days after sowing (Radha Kumari et al., 2015). 


\section{Results and Discussion}

Trails on direct sowing of rice were conducted at two different villages of South Bastar Dantewada district of Chattishgarh during kharif 2019-20.

The result shown in table 2 the comparison in various parameters for broadcasting and direct sowing by paddy drum seeder i.e. seed rate $\mathrm{kg} / \mathrm{ha}$, yield $\mathrm{q} / \mathrm{ha}$, cost of cultivation Rs/ha, Gross return Rs/ha and B:C ratio. The result shown that the treatment $\mathrm{T} 1$ and $\mathrm{T} 2$ gave the average net income $18689 \mathrm{Rs} / \mathrm{ha}$ and 27315 Rs/ha By sowing through traditional method $\mathrm{T} 1$ it was found that the yield $\mathrm{q} / \mathrm{ha}$ and $\mathrm{B}: \mathrm{C}$ ratio were recorded as $21 \mathrm{q} / \mathrm{ha}$ and 1.66 respectively. Sowing of paddy by paddy drum seeder T2, has recorded higher grain yield
$26.28 \mathrm{q} / \mathrm{ha}$ and $\mathrm{B}: \mathrm{C}$ ratio 2.42 which was $20.09 \%$ higher over broadcasting method T1 $21 \mathrm{q} / \mathrm{ha}$.

The net income was obtained $31.57 \%$ higher in sowing of paddy by paddy drum seeder as compare to the broadcasting method; this might be due to the lesser cost of cultivation \& higher yield as compare to broadcasting method. Sowing of paddy by paddy drum seeder T2, has calculated cost of cultivation $19898 \mathrm{Rs} / \mathrm{ha}$ and in broadcasting method T1 $23124 \mathrm{Rs} / \mathrm{ha}$. It was clearly showed that the sowing of paddy by paddy drum seeder reduces cost of cultivation. Higher net returns and $\mathrm{B}: \mathrm{C}$ ratio were recorded with drum seeder method due to less seed purchasing cost, reduced labor for weeding.

Table.1 Following information considered to execute the experiment

\begin{tabular}{|l|c|c|}
\hline Parameter & \multicolumn{2}{|c|}{ Treatments ( Paddy Variety-MTU1010) } \\
\hline & T1 (farmers practice) & $\begin{array}{c}\text { T2(Sowing of paddy by drum } \\
\text { seeder) }\end{array}$ \\
\hline $\begin{array}{l}\text { Speed of operator with drum } \\
\text { seeder, } \mathbf{~ k m} / \mathbf{h r}\end{array}$ & - & 1.5 \\
\hline Seed rate $\mathbf{~ k g} / \mathbf{h a}$ & 36 & 63 \\
\hline
\end{tabular}

Table.2 Comparison in various parameters in traditional method and direct sowing by paddy drum

\begin{tabular}{|c|c|c|}
\hline Parameter & \multicolumn{2}{|c|}{ Treatments } \\
\hline Cost of cultivation & T1 (farmers practice) & T2(Sowing of paddy by drum seeder) \\
\hline (Rs/ha) & 23124 & 19898 \\
\hline Gross Return (Rs/ha) & 38587 & 48237 \\
\hline Net Income (Rs/ha) & 18689 & 27315 \\
\hline Yield (q/ha) & 21 & 26.28 \\
\hline B:C Ratio & 1.66 & 2.42 \\
\hline
\end{tabular}



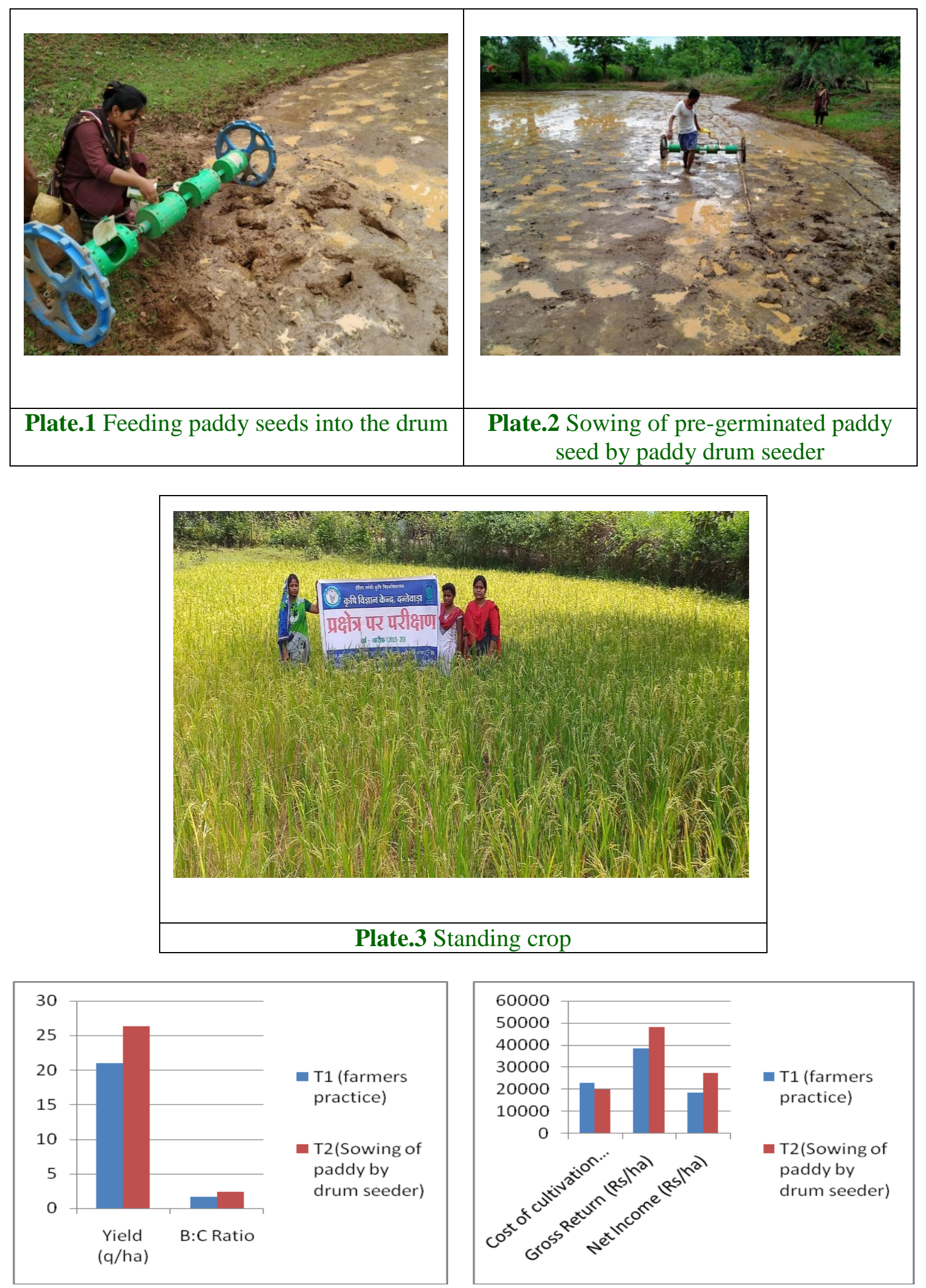

Plate.4 Comparisons in economic parameters between Traditional method and Sowing of paddy by eight row paddy drum seeder 
In conclusion, it is a best suited technology for the farmers as compare to traditional method. Mainly it reduces labour during peak periods i.e. transplanting, moreover it is technically viable and economically feasible and it is easy to practice without affecting the crop yields and help to make easy the weeding operations also by using mechanical weeder i.e. Ambika Paddy Weeder in line sowing keeping row spacing $20 \mathrm{~cm}$ and plant to plant spacing can also be increased by blocking the holes on the drum as per requirement. It gives $20.09 \%$ increases in yield. Direct sowing of pre-germinated paddy seeds by eight row paddy drum seeder help to reducing the cost of cultivation and increasing the net income.

\section{References}

Chandrasekhararao, C., Jintendra, S. and Murthy, T.G.K., Resource Optimization in Rice through Direct Seeding by Drum Seeder. Int J. Ag. Food Sci.
Tech., 4: 239-46 (2013).

Kumari, C. Radha and Sudheer, M. John (2015) On-farm evaluation of paddy drum seeder (8row) in farmers fields. Advance research journal of crop improvement vol.6, Issue 2: 139-143

Murumkar, R.P., Dongarwar, Usha R., Pisalkar, P.S. and Phad, D.S. (2014) Evaluation of Field Performance of Eight Row Paddy Drum Seeder. International Journal of Innovative Science, Engineering \& Technology, Vol. 1 Issue 9.

Sinha, A.K., Verma, A., Sinha P., and Chandrawanshi S.S., Assessment of eight row paddy drum seeder for sowing of sprouted/ pregerminated paddy seeds. Bull. Env. Pharmacol. Life Sci., Vol 6 Special issue [3] 2017: 128- 133 Bull.

Subbaiah, S.V., Balasubramanian, V. and

Krishaiah, K. (2002). Evaluation of drum seeder in puddled field conditions. Agricultural Mechanization in Asia, Africa and Latin America. 33(4): 23-41

\section{How to cite this article:}

Anita Lakra, Narayan Sahu and Diproshan Banjara. 2020. Assessment of Paddy Drum Seeder (8 Row) for Line Sowing of Sprouted Paddy Seed. Int.J.Curr.Microbiol.App.Sci. 9(07): 20002004. doi: https://doi.org/10.20546/ijcmas.2020.907.229 